\title{
The Influence of Inter-subjectivity on the Right of Speech in College Ideological and Political Education
}

\author{
Zhang Wenxiao \\ School of Foreign Languages \\ Xi'an Technological University \\ Shaanxi Xi'an, China \\ e-mail: 29958815@qq.com
}

\author{
Xie Junqiang, Li Ying, HuYan Xiaorong, Wang \\ Dandan \\ School of Computer Science and Engineering \\ Xi'an Technological University \\ Shaanxi Xi'an, China \\ e-mail: 1836154056@qq.com
}

\begin{abstract}
At present, the idea of inter-subjectivity education has become the leading thought of constructing harmonious teacher-student relationship and reforming the subjective ideological and political education. The way of ideological and political education, which regards the education receiver as the object, is not suitable for the development of the times. We now acknowledge that both of the educator and the education receiver are the subjects, and the relationship between the educator and the education receiver is like the relationship between "You and Me". Also the teacher no longer regards the education receiver as the object of "the other". It is a new subject in inter-subjective philosophy to recognize and deal with inter-subjectivity in educational relations. This paper focuses on the influence of inter-subjectivity theory on the right of speech in Ideological and political education.
\end{abstract}

Keywords-Inter-subjectivity; Right of Speech Ideological and Political Education; Influence

With the change from subjectivity to inter-subjectivity, main body education concept also moves from subjectivity to inter-subjectivity and has become the value pursuit of modern education. Marx pointed out that the essence of man is the sum total of all social relations. At the same time, People are realistic, concrete, historical and practical. One can be regarded as a true man only in social relations. In the relationship of inter-subjectivity education, the mode of existence between the educator and the education receiver is like the mode of existence of the subject. Inter-subjectivity education regards the education receiver as another subject in equal status with the educator. Both of them are subjective and constitute the "subject to subject" relationship. The Educator and the education receiver exist at the same time and they depend on each other. Educational materials serve as common objects for educators and education receiver. The thoughts of Inter-subjectivity break the relationship model of the absolute authority of teachers which exists in ancient education and lasts for thousands of years. Meanwhile, it eliminates the thinking set that the teacher-student relationship was deemed as subject-object relation. As a revolution in the history of educational development, it is of great theoretical and practical significance to effectively grasp the idea of inter-subjectivity in the study of the right of speech in the ideological and political education.

\section{AN OVERVIEW OF "INTER- SUBJECTIVITY"}

"Inter-subjectivity" is a very important concept in western philosophy in the 20th century, which is a new philosophical paradigm proposed by western philosophers headed by Husserl, Heidegger and Habermas in the theories of traditional epistemology, existentialism, and communicative behaviour. Husserl invented the term "inter-subjectivity" for the first time in Cartesian Meditations. In Husserl's view, subjectivity means oneself, while inter-subjectivity means self-community which is exactly we ourselves. He argues that the principle of 
subjectivity is a kind of individualism with a selfish tendency, and that the principle of inter-subjectivity encompasses the concept of collectivism. Heidegger argues that inter-subjectivity is a common thing between a subject and another, which is the identity of the same object with others. Habermas argues that inter-subjectivity is the spiritual communication, moral sympathy, mutual understanding and consensus that people form in the language communication. In general, inter-subjectivity is the certainty of relationships between subjects, which is the relevance, consistency and adjustability between subject and another. As shown in the figure 1.

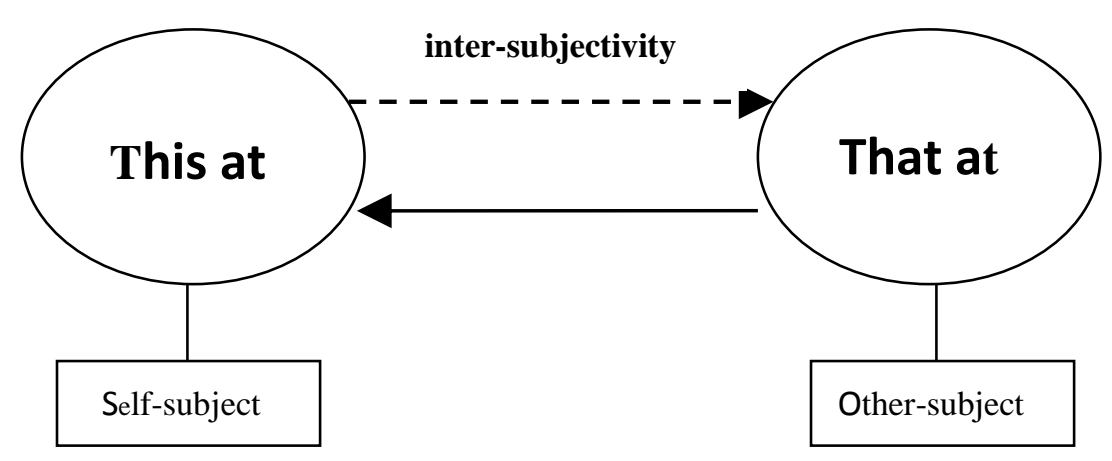

Figure 1. Schematic Diagram of Inter-subjectivity

The inter-subjectivity transcends the idea of individual subjectivity which occupies the subject-object relationship, and places the subjectivity between the subjects. Each subject is in its own-relationship, and has a relationship with each other in the concept of harmony in diversity. This kind of inter-subjectivity provides a new philosophical paradigm and methodology for the promotion of discourse power in ideological and political education.

\section{INTER-SUBJECTIVITY AND THE DISCOURSE RIGHT OF IDEOLOGICAL AND POLITICAL EDUCATION}

In inter-subjective ideological and political education, the activities between educators and education receivers are kinds of communicative activities. The practice of ideological and political education is the intermediate link between educators and education receivers, and forms the communicative activities of ideological and political education. In this process of communication, the subject of the educator and education receiver forms the ideological and political education inter-subjective relationship through equal dialogues and interactions. It is the coherence taking "interaction subject" as the core between the two subjects in the process of ideological and political education. In essence, it's a communicative relationship of inter-subjectivity and objectification, meanwhile the educators and education receivers can understand each other. In the perspective of inter-subjectivity theory, educators and education receivers interact with each other in the process of communication practice. Educators enhance the ideological and moral characters of education receivers through empathy. Education receivers are the subject of self-development. The dialogues, in essence, are communications between the two subjects. On the basis of mutual understanding, the educators and education receivers reach a cognitive and emotional consensus and integration, through the two-way communication and equal dialogue, and become the active subjects of education, as to achieve the goals of ideological and political education effectively.

The ideological and political education of college students is a kind of practice of political, ideological, moral, psychological education and other practical activities carried out by the ideological and political educators in colleges, according to certain social and political requirements, ideas, moral norms, using various environments, mechanisms, 
carriers and other means, to impose a planned and organized influence on the education subject. The discourse of ideological and political education refers to the communication, propaganda, persuasion and guidance from the educators to the education receivers in the specific discourse context of certain discourse norms, rules and laws under the domination of certain social dominant ideology. It is a language symbol system of interpretation, explanation, evaluation and construction concerning the content of ideological and political education, the concept of inter-subject, value orientation and behavioural characterization, involving the discourse power, inter-discourse, discourse context and text analysis and so on. The idea of inter-subjectivity is the prerequisite and basis for the effective development of the discourse right of ideological and political education.

\section{THE INFLUENCE OF INTER-SUBJECTIVITY ON THE RIGHT OF} SPEECH IN IDEOLOGICAL AND POLITICAL EDUCATION.

Nowadays, facing the impact and baptism from the We-Media, the discourse of ideological and political education presents typical features of multimodal, individuation and Inter-subjective interaction. Massive circulation of information deconstructs the right of speech in ideological and political education. And the inter-subjective interaction reduces the authority of discourse in ideological and political education. In the meantime, Multimodal propagation renews the ways of ideological and political education discourse.

Therefore, it is extremely urgent for the workers of ideological and political education to join the college students' daily life with equal sense of dialogue, establish a new type of inter-subjective communication relationship and strengthen the right of speech in ideological and political education.

\section{A. The inter-subjective consciousness between subjects is} the basis of constructing the system of discourse of both parties.

The process of inter-subjectivity ideological and political education is a two-way interactive process, which takes the inter-subjective consciousness as the starting point. The direct object each participant in the educational activity faces is not the other, but the inter-subjective relationship or the discourse text.

In the course of education, realizing the improvement of the ideological and moral character of the educator and the education receiver simultaneously is a manifestation of the overall progress of the whole of society. The discovery of others in oneself and the discovery of oneself in others are the essence of association. The discovery of others in oneself and the discovery of oneself in others are the essence of association. In the process of mutual understanding and interaction, the self-existence of oneself and others is identified. Educators should learn from others' strong points and close the gap. The educator and the education receiver can achieve the mutual transformation of the role on different occasions. Therefore, educators should take themselves as learners and lay down the role of the leader in the ideological and political education and be the participant. In the process of education, educators should be aware of the shortcomings of their own knowledge and the inadequacy of their abilities, and learn from the education receiver. Finally, both sides of education can improve the overall quality and achieve a win-win situation. In addition, the educators should cultivate the student's independent personality and foster them to be versatile talents with wide adaptability rather than training standard talents according to the same educational model. In this way, educators and education receivers will be able to communicate on an equal footing, understand mutually, produce a common topic, and promote the realization of educational objectives and the improvement of educational efficiency.

B. The inter-subjective equal communication is an effective way to dissolve the right of discourse in ideological and political education and defuse the crisis.

Between the main model of communicative ideological and political education is subject-object-subject, admitting the educator and the educated are the equal subjects, and they abandon the relationship between them and establish one with them. In the "You and Me" dialogic relationship, educators and the educated share the equal right to speak. 
They achieve the ideological and political education object on the basis of mutual respect, through an open, interactive, two-way communication model. This relationship breaks the opposing atmosphere between teaching and being taught, subjective-objective and changes the vertical relationship between the educator and the educated. Meanwhile, this develops and promotes their subjective consciousness of the two sides in the interaction of multi-polar subjects and effectively breaks the closure of the subjectivity education thought. In the equal and cooperative relations, it is useful for the two sides to facilitate the in-depth dialogue in thought and emotion and eliminate the self-subject, estrangement and misunderstanding, so as to promote the two sides of their greater horizon and communicative need, understand the education needs and goals. They also can share knowledge, feeling and wisdom to forge the framework of inter subjectivity communication, so as to enhance the teacher-student relationship, resolve the ideological and political education discourse of the crisis and to realize the aim of education.

\section{The living world between the subjects can effectively} construct ideological and political education and simple and understandable speech system.

In Habermas's view, the life world is the context in which the capable speaker is thrown into. The context is the common, non-thematic background knowledge which is necessary for mutual understanding in communicative behaviour. Each subject is growing in the world and has different degrees of understanding of mortality and norms. These feelings opinions and understandings are the ideological source of equal educational dialogue and emotional communication and they are also the most integrated and complete carrier and foundation of ideological and political education. Therefore, strengthening the relation between the ideological and political education and real life makes the education go through from abstract to concrete and from empty to lively. In real life, taking the education as the background of constructing the content of political and educational is the foundation of having a common language to communicate between the educator and the educated. The inter subjectivity of ideological and political education is to guide the subjective personality to the inter-subjective one and enhance the correct understanding and handling of man and nature, man and society and himself and myself relationship, to make education return to "life world", thus causing the educated ideological resonance formation and educators can understand each other's language system, active consciously and accept the education content. Only in this way, can we reach a consensus on mutual understanding and happiness education environment, and break the monologue of the situation, to achieve the purpose of Ideological and political education with discreet language system.

\section{The practice standard of inter-subjectivity is an} effective means to improve the executive efficiency of discourse power in ideological and political education.

The inter-subjective ideological and political education advocates that educators should take full account of the characteristics of the physical and mental development of the educated and the degree of acceptance of the educational content by the educated, and take the scientific education method to achieve the best results. The essence of man is the sum total of all social relations. Marxism thought that practice is the most essential characteristic of human and society. If we talk about people and society without practice, we will fall into metaphysics. Man is a realistic, historical, concrete and practical person who becomes a real person only in a practical social relationship. The content of ideological and political education only place in the complex social life, then can tell what is not true or false, in order to effectively carry out criticism and absorption, consolidation and reconstruction. Therefore, educators should guide the educated actively participate in practical activities, from passive to lead, from rational awareness to guide the practice of rational and accept the practice, and constantly improve and enhance. Only in this way, can we realize its subjectivity and internalize the content of ideological and moral education into practical codes of conduct, through the practice of internalizing the content of education. Thus, the social class and education closely linked together, to form an organic integration, and to make the educated understand the national conditions, social conditions and public opinion, 
therefore it can broaden their horizons, and enhance practical ability, growth ability. We should internalize the ideological and political education language into practical action, so as to improve the effectiveness of ideological and political education discourse.

\section{REFERENCE:}

[1] Liu zheng. The Research of Inter-subjectivity Ideological and Political Education. Master Thesis, Shan xi Normal University ,Xi'an China, 2011.
[2] Xiang Xuwei. Research on Discourse of the Modern Ideological and Political Education. Doctoral Thesis, Nan Chang University, Nan Chang China, 2015.

[3] Zhou Bo. Habermas' Theory of Communicative Action and Its Enlightenment. Journal of ShengYang University, 2010, 22, 1008-9225 (2010) 06-0106-03

[4] Feng Janjun. Inter-subjectivity and educational communication. Journal of Higher Education, 2001, 22, 1000-4203(2001)06-0026-06

[5] Xie Rong, Lian Yongjie. Inter-subjectivity: the fundamental value of modern education. Journal of Nanchang College of Education, 2011, 26, 1008-6757 (2011) 01-0108-01.

[6] LI Yinying .World of Education and World of Life Revisited. Journal of Hebei Normal University (Educational Science Edition), 2008, 10 1009-413X (2008) 06-0027-02 